\title{
Problems and Countermeasures of Graduation Design(Thesis) in Independent Colleges
}

\author{
Boquan Jiang \\ Department of Chemistry and Biology, \\ Institute of Science, \\ Nanchang University College of \\ Science and Technology, \\ Nanchang, Jiangxi, \\ 330029, China \\ jbq_win@163.com
}

\author{
Zhengping Chen \\ Department of Chemistry and Biology, \\ Institute of Science, \\ Nanchang University College of \\ Science and Technology, \\ Nanchang, Jiangxi, \\ 330029, China \\ 496901958@qq.com
}

\begin{abstract}
Graduation Design(Thesis) is an important practical link in independent college. In order to achieve effective teaching results, several problems existing in the Graduation Design(Thesis) were analyzed and the corresponding countermeasures were proposed, including increasing the students' interests and enthusiasm, making full use of the teaching resources within and outside the college, strengthening the guidance of graduation design (thesis) and intensifying the management and quality control of Graduation Design (Thesis).The results show that these countermeasures can increase the students' interests and enthusiasms to attend the Graduation Design(Thesis), ensure desired teachers, projects and laboratories, strengthen the guidance of Graduation Design(Thesis) by the tutors and cultivate the students' conscious activities and innovations.
\end{abstract}

Keywords-graduation design(thesis); independent college; problems; countermeasures

\section{INTRODUCTION}

Independent college is made up of ordinary undergraduate course college and university (applicant) and social forces (partners, including enterprises, institutions, social organizations or individuals, and other institutions having cooperation ability). It is a higher education institution at the undergraduate level and a model of the secondary college of undergraduate level held in accordance with the new mechanism and model. The establishment of independent college is a major measure to ensure the sustainable and healthy development of higher education and it has become an important part of higher education development in China, which will be a focal point of the development of higher education for a period of time in China. After the first round assessment of undergraduate course by the Chinese ministry of education in 2008, the independent college has established the positioning of applied undergraduate education combined with practical spirit of education policy and its development goals. As an emerging force in education, the independent college is focusing on cultivating high-quality applied talents and serving the market economy construction and social development. The talents training target of the independent college must be geared to the needs of market economic construction[1-4].The cultivated talents should be "mastering many skills while specializing in one" with strong practice ability, good beginning ability and strong innovative spirit. Graduation design(thesis) (abbreviated as $\mathrm{GD}(\mathrm{T})$ ) is an important practical teaching link focusing on cultivating the students' comprehensive quality, practice ability and innovative spirit. The link is an important part of the training plan, by which the students receive comprehensive professional practice training, cultivate their scientific and engineering abilities and improve their capacities of analyzing and solving practical problems using learned basic theories and professional knowledge. The conduct of $\mathrm{GD}(\mathrm{T})$ is an examination of professional cultivate target and reflects the education quality of the college from a certain extent. Since more than ten years, the independent college has rapidly developed. However, its overall quality of $\mathrm{GD}(\mathrm{T})$ is not high due to its short history and lack of experience[5-6]. Therefore, how to improve the GD(T) quality has become an important project for the independent college to focus on and research. This paper pays more attention to analyzing the problems existing in $\mathrm{GD}(\mathrm{T})$ and proposing some corresponding countermeasures.

\section{PROBLEMS EXISTING IN GD(T)}

\section{A. Lack of enough attention to $G D(T)$}

A certain percentage of the students have no correct understanding of the importance of GD(T). Some of them lack confidences to finish the $\operatorname{GD}(\mathrm{T})$ due to their poor foundation. Some of them pay more attention to looking for their jobs than do the GD(T) during the GD(T) time. Some of them do not want to do their professional work after graduation and so they have no interests in $\mathrm{GD}(\mathrm{T})$ and are more interested in looking for a job, taking the examination for becoming a graduate student or civil servant or obtaining some working certificates. Some of them have the thoughts of fear of hardships and want to go "shortcut" to finish the GD(T) - plagiarism or copying from the other persons or internet. 


\section{B. Lack of enough teachers, projects and laboratories}

The GD(T) requires the students to have "one project one student", for which sufficient quantity of teachers, projects and laboratories should be ensured. However, at the moment, the limited teachers employed by the independent college are young teachers and the senior teachers with high academic level and rich practical experience are fewer, which can't satisfy the requirement of "one project one student" and obtain high quality of GD(T). Many of the young teachers have heavy teaching tasks and no enough time and energy to prepare and apply for the longitudinal research projects, including national and provincial level projects, and are difficult to obtain the crosswise projects from enterprises due to their lack of high academic level and rich engineering experiences. In addition, the laboratory and equipment in the independent college can't meet the needs of GD(T) due to "one project one student".

\section{Lack of enough guidance for $G D(T)$ by the teachers}

In the independent college, the young teachers bear heavy teaching task because their wage incomes are mainly determined by the number of teaching hours, so within the period of $\mathrm{GD}(\mathrm{T})$, some of them spend a lot of time to the theoretical courses or other teaching links but less time to guiding the GD(T).The students, who are ready for taking part in the postgraduate entrance exams, practically start their GD(T) after the second reviews, so their GD(T) tine is not sufficient and can't receive the normal guidance from the tutors. Some of the students, who have signed the employment intention agreement with the enterprises, have to go to the enterprises for a period of practice and so they are far away from the college and can't also get the normal guidance of the tutors.

\section{Lack of effective management and quality control of $G D(T)$}

Some students do not pay great attention to the GD(T). They can't finish their task independently through their own efforts. Some students have relatively less time for $\operatorname{GD}(T)$ because of their being ready for taking part in the postgraduate entrance exams or going to enterprises for practice. These phenomena cause the students some bad behaviors, such as partially plagiarism and copying from the internet and some scientific papers database, and even a few students pay someone else to write design specifications or research papers. These bad behavior seriously affects the quality of GD(T).

\section{COUNTERMEASURES}

\section{A. Increasing the students' interests and enthusiasms}

In order to increase the students' interests and enthusiasms of attending the $\mathrm{GD}(\mathrm{T})$, we invite senior old professor, outstanding teachers, enterprise engineering specialists and open the course of "introduction to 'professional' " to repeatedly explain to the students and emphasize the importance of $\mathrm{GD}(\mathrm{T})$. We have talks with some students, whose scores are not good, to encourage them improve their academic level or engineering design ability through hard work during the $\mathrm{GD}(\mathrm{T})$. For those students who originally intend to copy others work, we educate them to cultivate the quality of seeking truth from facts and proud of the good faith. When some of students encounter thorny and difficultly solved problems during their experiment or engineering design, the tutors timely give them enthusiastic guidance and inspired them to use learned theory knowledge to analyze and solve these problems. These measures obtained good results and make the students clearly understand the significance of GD(T) i. The $\operatorname{GD}(\mathrm{T})$ is an important way of theory with practice and they can review and apply their learned knowledge to complete a research project or an engineering design project; ii. Through the $G D(T)$, they can grasp scientific research method or engineering design method, which is very important to their future work. iii. Through the $\mathrm{GD}(\mathrm{T})$, they can learn many new knowledge, such as synthetic materials balance, heat balance, and equipment calculation of a technological process or a product design. iv. The $\mathrm{GD}(\mathrm{T})$ is an important practice for them before they leave the college and go to work. v. The $\mathrm{GD}(\mathrm{T})$ can train their abilities of independently analyzing and solving practical problems and cultivate their strong creative consciousness.

\section{B. Making full use of the teaching resources within and outside the college}

In order to achieve the request of "one project one student", sufficient teaching resources are the important guarantee of $\mathrm{GD}(\mathrm{T})$. According to the practical situation of the college, the teachers are not enough and most of them are young so that they can't undertake the whole GD(T) task[7-10] To ensure the quality of $\operatorname{GD}(T)$, we make full use of the teachers within and outside the college. These teachers include the young and old teachers employed by the college (the number of the students instructed by the young teachers is limited to be three), the middle-aged and old teachers with high academic level and rich practical experience in the mother university (Nanchang University), the senior engineering and technical personnel in the production and practice bases cooperated with the college and the senior engineers in the enterprises where the students have practices. The abundant teacher resources brought about plenty of design and research projects, involving the national natural science foundation of China, national science and technology support project, natural science foundation of jiangxi province, jiangxi science and technology support projects, science and technology project of Jiangxi education department, scientific research fund of Nanchang university college of science and technology and scientific research and engineering design projects of enterprises and companies, etc.. The abundant teacher resources also brought about good experimental and design conditions. Nanchang University is one of the key construction universities of "211 project" in China and it possesses a lot of advanced scientific research equipment and instrument, and standard laboratories. The enterprises and companies can provide applied subjects and progressive equipment and instruments. The making full use of the teaching resources within and outside the college offered the students a plenty of projects to select according to their interests and practical conditions and provided the advanced research contents and practical engineering design.

\section{Strengthening the guidance of graduation design (thesis)}

The GD(T) was originally arranged in the last semester. However, during the $\mathrm{GD}(\mathrm{T})$ time, some students are ready for 
the postgraduate examination and some students have practices in the enterprises before their getting jobs, which take them a lot of time and can't get the normal guidance from the tutors. In order not to affect their preparations and practices but successfully conduct the GD(T) for obtaining a good results, the $\mathrm{GD}(\mathrm{T})$ is now arranged in the fourth year in advance, meaning that the GD(T) can be finished in a period of one year. The students can be divided into four parts:(i) those who stay at the college without taking the postgraduate examination and practices in enterprises; (ii)those who stay at the college ready for taking the postgraduate examination and the second reviews if they pass through the examination; (iii) those who go to the enterprises for practices before getting jobs.(iv)those who select the project from the enterprises and are guided by the senior engineers. On the premise of GD(T) time of 15 weeks, the students can reasonably arrange the $\operatorname{GD}(\mathrm{T})$ schedule according to their concrete conditions. For the students of part(i) and part(ii), the tutors guide them at the specified time and place and check their study conditions in time, strictly on the basis of the schedule. While the students have some problems, they can make a phone call or email to the tutors at any time, and the tutors will timely and gladly to answer them.For the students of part (iii), the tutors give them the guidance by email or telephone when they work in the enterprises or companies. For the students of part (iv), their tutors will give them the assignments and guide them according to the schedule.

\section{Intensifying the management and quality control of $G D(T)$}

Strictly grasping the $\mathrm{GD}(\mathrm{T})$ process management is the important guarantee to improve the quality of $\mathrm{GD}(\mathrm{T})[11-12]$. In order to achieve the intended purpose, we strictly checked on the important links of GD(T), including assignment book(written by the tutors), project selection, opening report, English-Chinese translation, project design (experiment), writing design specification (thesis), developing chemical drawings by computer (AutoCAD) and oral defense. The students were required to fulfill the task of each link and submit to the tutors to check. The tutors carefully reviewed and put forward the amendments. In the experiment, we gave full play to the main body motility of the students and required them independently design the experimental scheme, set the experiment device, operate the experiment process, processing the experimental data and write the thesis. In order to make the students write the design specifications or thesis in standard, the tutors usually reviewed and the students usually modified the design specifications or thesis for several times. Moreover, in order to prevent the student from plagiarism or copying others' works, the college established the "paper rechecking system". The dissertation of each student must pass through the check by the system. If the reproduction ratio of the dissertation is over $30 \%$, it will not be allowed to pass, which effectively promoted the students to independently finish the $\mathrm{GD}(\mathrm{T})$ and cultivated their conscious activities and innovations.

\section{CONCLUSIONS}

The problems of GD(T) existing in the independent college were presented, including lack of enough guidance for GD(T) by the students, lack of enough teachers, projects and laboratories, lack of enough guidance for $\mathrm{GD}(\mathrm{T})$ by the teachers and lack of effective management and quality control of $\mathrm{GD}(\mathrm{T})$. Aiming at these problems, the corresponding countermeasures were proposed, which increased the students' interests and enthusiasms to attend the GD(T), ensured desired teachers, projects and laboratories, strengthened the guidance of $\mathrm{GD}(\mathrm{T})$ by the tutors and cultivated the students' conscious activities and innovations.

\section{REFERENCES}

[1] X J Yuan. Applied Talents is the Best Choice of the Talents Training Target of Independent Colleges[J]. Education Teaching Forum, 2014, Issue 25,pp.230-231.

[2] Y M Liu, J Liu. Discussion on Cultivating Applied Talents in the Independent Colleges $[\mathrm{J}]$. Journal Beijing University of Chemical Technology(Social Sciences Edition) ,2013, Issue 82(total), pp.85-88.

[3] L J Cheng, L N Wang. Analysis of the Mode of Talents Cultivation of Independent College Under the New Situation[J]. Journal of Tangshan Teachers College, 2013, Vol.35, Issue 5,pp.113-114.

[4] T Liu. Culivation of Independent College Students' Innovation Abilities [J]. Journal of Hengshui University, 2013,Vol.15, Issue 2, pp.116-118.

[5] M F Wu, Y Q Fan, X Y Dai.Countermeasures and Thinking of Undergraduate Course Graduation Design (Thesis) Quality in Independent College[J]. Intelligence issue 2009, Issue 25, pp.247.

[6] C Ye, Y N Jiang, X M Lin. Diversified Graduation or Thesis in Independent Colleges[J].Journal of Ningbo University(Educational Science Edition),2012,34(5), pp.105-107.

[7] G S Ji, G C Zhang, M Zhao,et al. Countermeasures and Suggestions for Improving the Graduation Design (Paper) Qquality of Engineering Professional in Independent College[J]. Light Industry Science and Technology, 2012, Issue7, pp.150-152.

[8] M D Wang. Background and current situation of building the practical teaching system of independent colleges[J]. Science \& Technology Information, 2013, Issue 23, pp.208.

[9] $\mathrm{T} \mathrm{J} \mathrm{Li.} \mathrm{The} \mathrm{New} \mathrm{Educational} \mathrm{Reform} \mathrm{Idea} \mathrm{of} \mathrm{the} \mathrm{Independent}$ Colleges[J]. Science Tribune, 2013, Issue 2, pp.39-40.

[10] X B Lei. Thinking of improving the quality of undergraduate graduation design (paper) in independent college[J].Journal of Chifeng University (Natural Science Edition), 2014, Vol.30, Issue 6, pp.245-246.

[11] S P Xu, C L Ye. Quality Analysis and Countermeasures of the Independent College Graduation Project (Thesis) [J]. Science Tribune, 2012, Issue3, pp.172-173.

[12] W H Wang. Quality Analysis on Thesis and Countermeasures of the Independent Colleges in Zhejiang Province [J]. Journal of Ningbo University(Educational Science Edition), 2011, Issue35, pp.69-72. 